
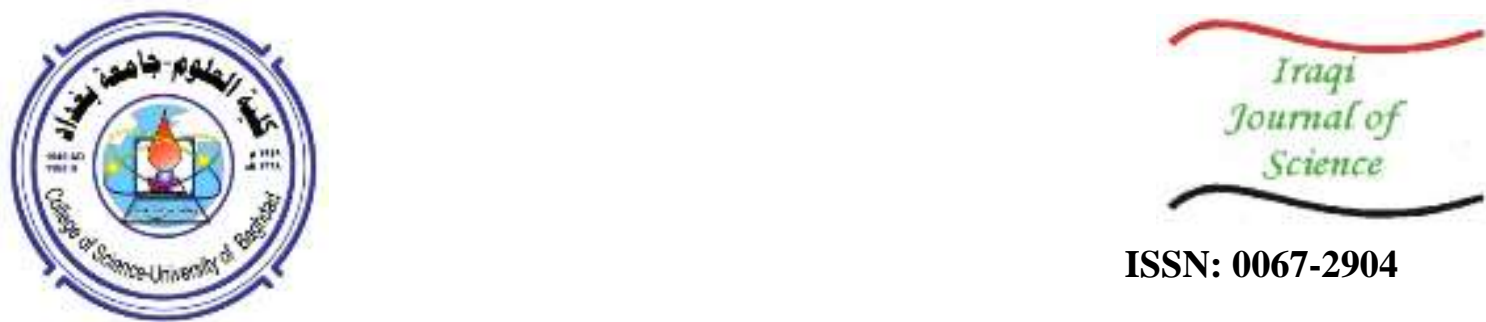

ISSN: 0067-2904

\title{
Isotopic Study of Springs Near Haditha Dam Western Iraq
}

\author{
Mohammed Ibraheem ${ }^{1}$, Kamal B. Al-Paruany ${ }^{2}$,Enaam J Abdullah ${ }^{1}$ \\ ${ }^{1}$ Department of Geology, College of Science, University of Baghdad, Al-Jaderia, Baghdad, Iraq. \\ ${ }^{2}$ Ministry of Science and Technology, Directorate of Water Technology and Environmental Research, Al- \\ Jaderia, Baghdad, Iraq.
}

Received: 28/4/2019 Accepted: 20/ 8/2019

\begin{abstract}
Stable isotopic technique and hydrochemistry was used in studying the water resources interaction of near Haditha Reservoir area, western Iraq. Throughout the study area, 14 groundwater samples (Bashina, Zwachi springs and Wells), 8 surface water samples from the study area, and 7 spring samples were analyzed for ${ }^{2} \mathrm{H}$ and ${ }^{18} \mathrm{O}$ stable isotopes and hydrochemical analysis. In this study, the temperature, altitude and continental effects on the isotopic composition of rain water in Iraq were studied. The climate of the study area is classified as semi-arid to arid region. The results show a variation in the isotopic values of Haditha reservoir and Euphrates river. This variation is due to the effect of the low surface area and the low velocity of water of Haditha Reservoir on the amount of evaporation, compared with the high velocity and the large surface area of Euphrates river. There was a variation in the isotopic values between Bishina and Zwachi springs, due to two factors that appear to modify the isotopic signatures of the springs, namely the lack of hydraulic connection between the springs of Bishina and Zwachi, meaning that they recharge from different sources. The changes in oxygen isotope composition of the groundwater between a deep reservoir and the springs (Bishina) may be caused by the dilution with near surface waters (Haditha reservoir) with different oxygen isotope compositions. The variation in the isotopic content in the studied area indicated that there are various origins of springs recharge and a different interactions of the multiple sources of springs with the mutli-depths of springs water.
\end{abstract}

Keywords: Stable isotopes, Water resources, Springs, Haditha reservoir, Iraq

$$
\begin{aligned}
& \text { دراسة نظائريـة للعيون قرب سد حديثة غرب العراق } \\
& \text { كحمل إبراهيم1"، كمال البارواني² ، أنعام جمعه عبدالله } 1 \\
& \text { 1قسم الجيولوجيا ، كلية العلوم ، جامعة بغداد ، الجادرية ، بغداد ، العراق. } \\
& \text { 2وزارة العلوم والتكنولوجيا ، مديرية تكنولوجيا المياه وبحوث البيئة ، الجادرية ، بغداد ، العراق. }
\end{aligned}
$$

تم استخدام تقنية النظائر المستقرة والتحاليل الهيدروكيميائية في دراسة تداخل الموارد المائية بالقرب من

منطقة خزان حديثة غرب العراق, تم اخذ 14 نموذج من المياه الجوفية (ينابيع منطقة بشنة وزويجي والابار )

و 8 نماذج من المياه السطحية (نهر الفرات والبحيرة), تمت دراسة نظائر الأوكسجين 18 والديتيريوم ودرجة

الحرارة والارتفاع والتأثيرات الناتجة من تحليل النظائر المستقرة لمدة ساعتين وأيضا التركيب النظائري لمياه 


$$
\begin{aligned}
& \text { الأمطار في العراق. يصنف مناخ منطقة الدراسة على انه منطقة شبه جافة الى جافة, أظهرت النتائج وجود } \\
& \text { تباين في القيم النظائرية بين خزان حديثة ونهر الفرات بسبب تأثير الساحة السطحية لخزان حديثة وقلة سرعة }
\end{aligned}
$$

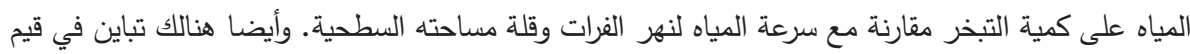

$$
\begin{aligned}
& \text { النظائر بين ينابيع بشنة وزويجي بسبب عدم وجود اتصال هيدروليكي بين ينابيع بشنة وزويجي وهذا يعني } \\
& \text { تغذيتها من مصادر مختلفة. التغيرات في تكوين نظير الاوكسجين للمياه الجوفية بين الخزان العميق للمياه } \\
& \text { وينابيع بشنة قد يكون سببها التخفيف مع المياه السطحية القريبة(خزان حديثة) بسبب تركيبات نظائر } \\
& \text { الاوكسجين المختلفة. من خلال معرفة الاختلاف في محتوى النظائر في منطقة الدراسة نشير الى وجود أكثر } \\
& \text { من أصل لتغذية الينابيع وهنالك ايضا تداخل في عدة مصادر للعيون في اعماق مختلفة. }
\end{aligned}
$$

\section{Introduction}

Since several decades, stable isotopes of the water molecule have been used as a powerful tool for tracing precipitation, groundwater recharge and origin, river/ groundwater exchange, hydrograph separation, basin water hydrology, the mixing of waters from different origins, evaporation, and the impact of climate change on groundwater. Isotopic compositions of hydrogen and oxygen of hot springs are regarded as effective proxies to trace water origin [1-5]. The $\delta \mathrm{D}$ and $\delta^{18} \mathrm{O}$ values of waters, especially when combined with the concentrations of conservative solutes, are the best geochemical indicators of origins, recharge locations, and flow paths. Many Hydrological studies have used the environmental isotopes to determine water origin, flow paths of water, recharge mechanisms, groundwater ages, solutes and solids reflecting groundwater quality, rock-water interaction, interaction between different water bodies, geochemical evolution, the salinity, and contamination processes [6,7].

In this study, a stable isotopic technique (deuterium and oxygen-18) was used to examine the interrelations among different water resources (springs water, wells, Haditha Reservoir and the Euphrates River.) in western Iraq.

\section{General characteristics of the study area}

The study area is located in the northwestern part of Al-Anbar Governorate, about $3 \mathrm{~km}$ from Haditha Dam. It is bounded by latitudes $34^{\circ} 03^{\prime} 27^{\prime \prime}$ to $34^{\circ} 15^{\prime} 17^{\prime \prime}$ North and longitude $42^{\circ} 20^{\prime} 45^{\prime \prime}$ to $42^{\circ} 33 ' 30 "$ East (Figure-1).

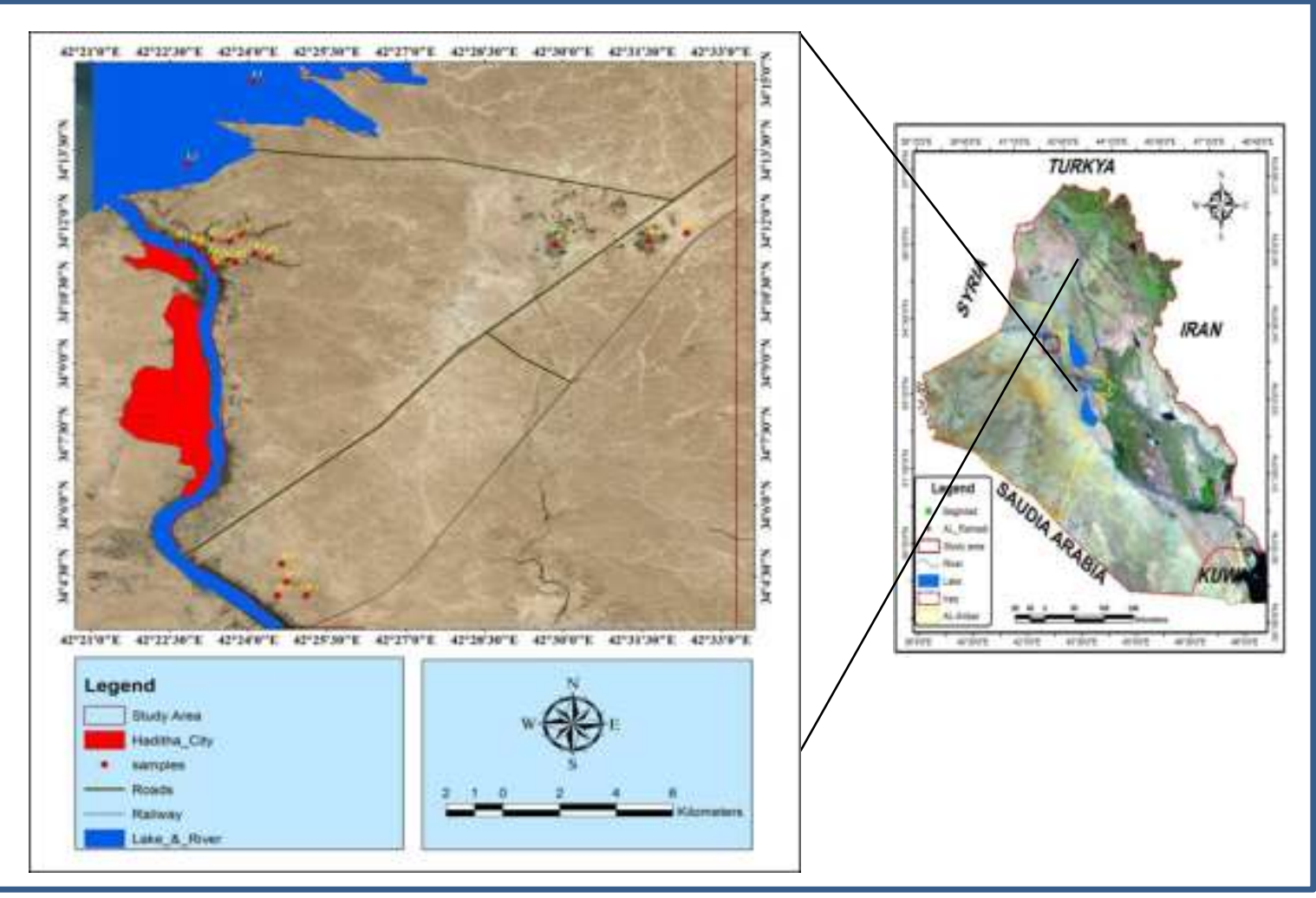

Figure 1-Location map of the sampling stations in the study area. 
The main geological formations in the study area are Euphrates Formation and Fatha Formation which represent sedimentary formations of the Miocene age. The study area is located in the eastern part of the stable shelf of Iraq within the Rutba - Jazera Zone. Euphrates and Abu- Jir fault zone are the main faults affecting the area [8,9]. The geomorphology of Haditha area include many features such as sinkholes, isolated hills, flood plains, and islands along the Euphrates River. Karsts caused by solution of limestone and gypsum occur in both Euphrates and Fatha Formations [10].

Climate information of the study area was obtained from the meteorological data provided by Haditha station for the period from 1980-2017, with an elevation of 108 m.a.s.l. Elements of climate were estimated as follows: the average annual rainfall is calculated to be $140.6 \mathrm{~mm} / \mathrm{year}$, the monthly average temperature is $22.9 \mathrm{C}$, the average relative humidity is $43.5 \%$, the average wind speed is $3.32 \mathrm{~m} / \mathrm{s}$, the average evaporation is $3064 \mathrm{~mm} /$ year and the annual evapotranspiration is $903.94 \mathrm{~mm}$. The study area could be classified as semi-arid to arid region according to Al-Kubaisi [11-16].

\section{Materials and methods}

Two visits were carried out to the study area. The first visit was conducted to determine the location of groundwater wells, springs, while the second one to select sites for surface water sampling in the Euphrates River and Haditha reservoir, taking into account that sampling of water should cover the whole study area. The fieldwork was carried out during two periods of March (2018) and August (2018). Twenty two samples were collected in glass containers $(50 \mathrm{ml})$ for isotopes analysis and hydrochemistry. Physical properties of water ( $\mathrm{pH}, \mathrm{EC}$ and T) were measured in the area. The isotope values of all water samples were analyzed by using Liquid Water Stable Isotopes Analyzer (LWSIAL) after calibration with accuracy constant. Results are expressed in \%, while the measurements of accuracy for $\delta^{18} \mathrm{O}$ and $\delta^{2} \mathrm{H}$ are $\pm 0.1, \pm 1.0 \%$ versus VSMOW, respectively.

Table 1-Locations of groundwater (Bishina Zwachi Springs and Wells) and surface water sites (the Euphrates River, Haditha Reservoir).

\begin{tabular}{|c|c|c|c|c|}
\hline Stations & Local name & latitude & Longitude & Elevation $(\mathbf{m})$ \\
\hline B1 & Bishina spring 1 & 34,187 & 42,406 & 94 \\
\hline B2 & Bishina spring 2 & 34,188 & 42,397 & 94 \\
\hline B3 & Bishina stream & 34,186 & 42,397 & 93.5 \\
\hline B4 & Bishina stream & 34,185 & 42,392 & 92 \\
\hline Z1 & Zwachy spring & 34,195 & 42,398 & 96 \\
\hline Z2 & Zwachy stream & 34,193 & 42.399 & 94 \\
\hline Z3 & Zwachy stream & 34,194 & 42,388 & 93 \\
\hline L1 & Haditha Reservoir & 34,249 & 42,4 & 132 \\
\hline L2 & Haditha Reservoir & 34,22 & 42,35 & 132 \\
\hline R1 & Before meeting with Zwachy & 34,193 & 42,394 & 87 \\
\hline R2 & Through meeting & 34,192 & 42.394 & 87 \\
\hline R3 & After meting & 34,19 & 42,394 & 86.9 \\
\hline R4 & Before meeting with Bishina & 34,187 & 42,4 & 86.8 \\
\hline R5 & Through meeting & 34,185 & 42,389 & 87 \\
\hline R6 & After meeting & 34,183 & 42,397 & 87 \\
\hline W1 & Ayed Hardan & 34,192 & 42,491 & 159 \\
\hline W2 & Ayweb Salaman & 34,073 & 42,412 & 153 \\
\hline W3 & Muayed Saihud & 34,068 & 42,415 & 107 \\
\hline W4 & Alaa Ayed & 34,079 & 42,414 & 98 \\
\hline W5 & Haj Jameel & 34,068 & 42,413 & 97 \\
\hline W6 & Salah Farhan & 34,193 & 42,527 & 156 \\
\hline W7 & Shaker mahoud & 34,196 & 42,543 & 155.7 \\
\hline
\end{tabular}

\section{Results and discussion \\ Hydrochemistry}

Figures-(2, 3, 4, and 5) show the chemical composition of samples in the study area for the wet and dry periods, March 2018 and August 2018. The dominant cations and anions in Bishina springs and stations W4, W5, W6, W7, and R3 were mainly of the order of $\mathrm{Na}>\mathrm{Mg}>\mathrm{Ca}>\mathrm{K}$ and $\mathrm{SO}_{4}>\mathrm{Cl}>\mathrm{HCO}_{3}$, 
while in Zwachi springs and stations R2, R5, R6, W1, W2, and W3 they were in the order of $\mathrm{Na}>\mathrm{Ca}>\mathrm{Mg}>\mathrm{K}$ and $\mathrm{Cl}>\mathrm{SO}_{4}>\mathrm{HCO}_{3}$. In Haditha Reservoir and stations R1 and R4, the order was $\mathrm{Ca}>\mathrm{Na}>\mathrm{Mg}>\mathrm{K}$ and $\mathrm{Cl}>\mathrm{SO}_{4}>\mathrm{HCO}_{3}$ in wet and dry periods. The chemical composition of the the samples characterizes the presence of Na-SO4 in Bishina springs and stations R2, R3, R5, R6, W2, W3, W6, and W7, while $\mathrm{Na}-\mathrm{Cl}_{2}$ was characteristic in Zwachi and stations W1, W4, and W5, and Ca$\mathrm{Cl}_{2}$ was characteristic in stations $\mathrm{R} 1$ and $\mathrm{R} 4$.

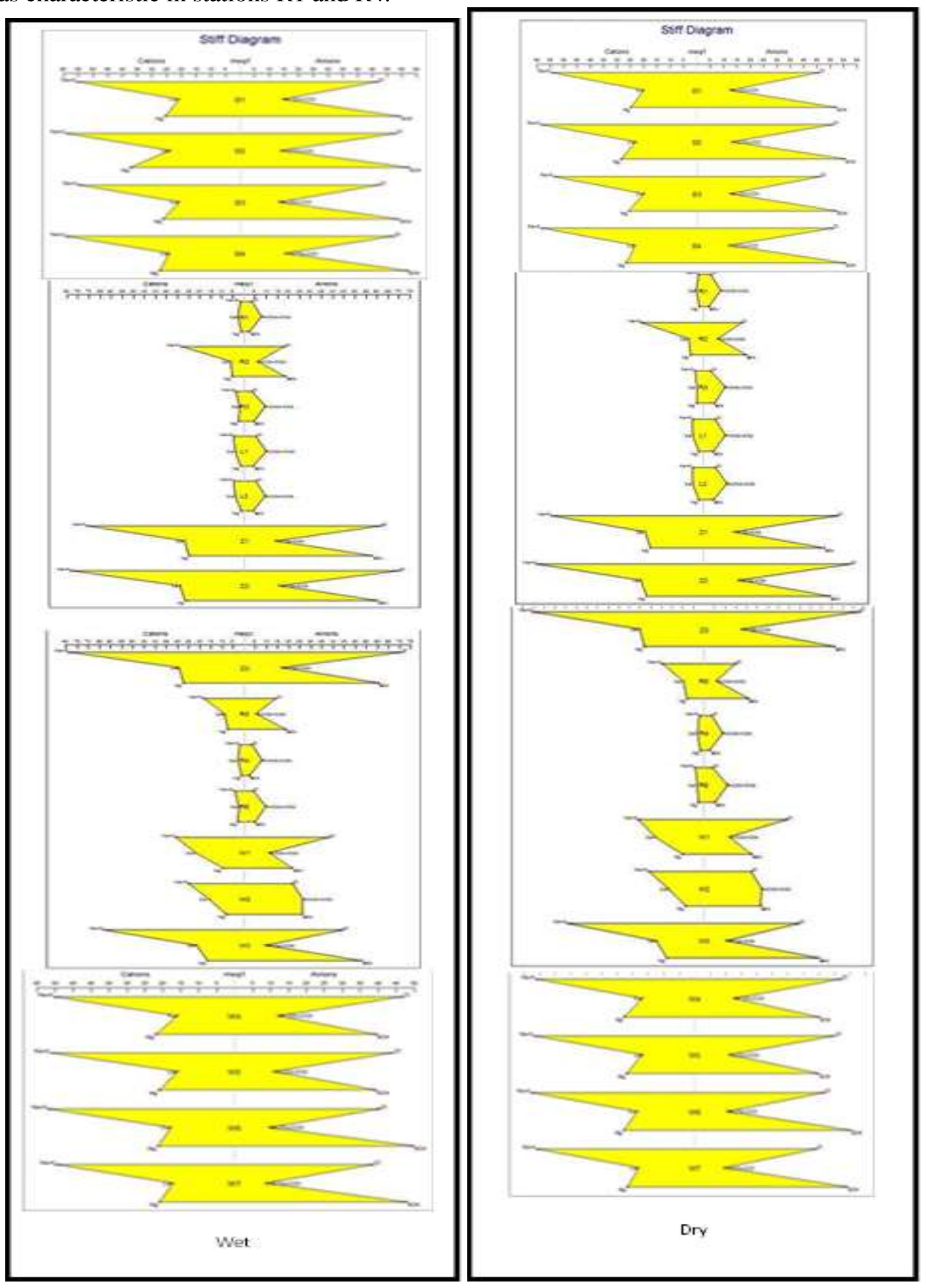

Figure 2-Stiff diagram of the water samples in two periods. 


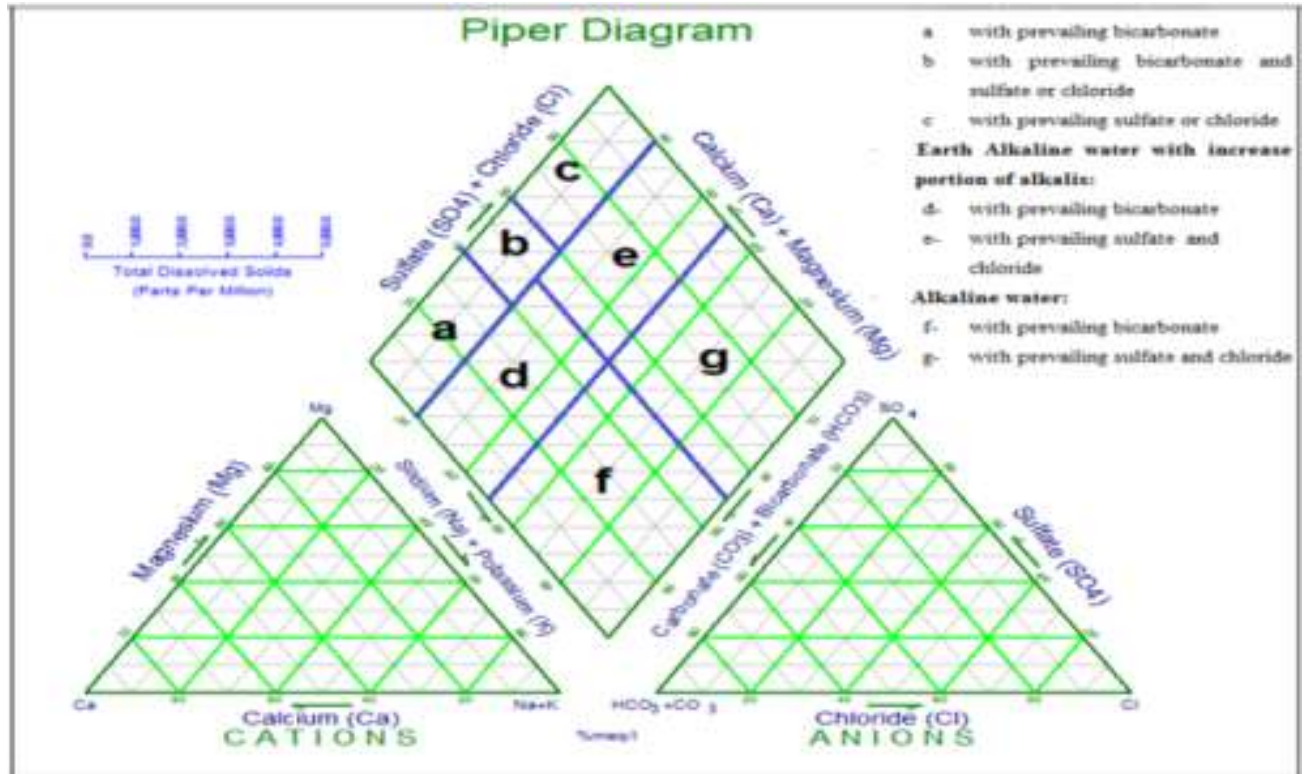

Figure 3-Piper triangular diagram, with the divisions of Langguth, (1996), [12].

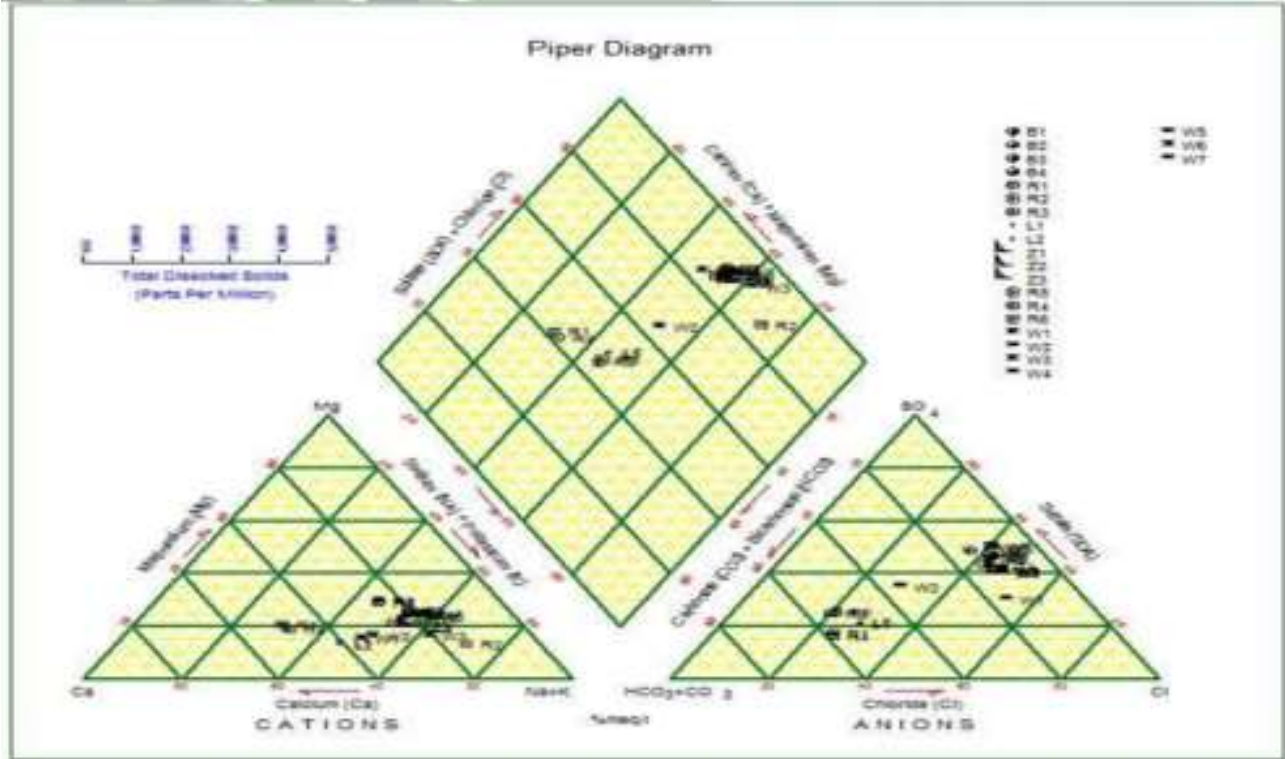

Figure 4-Piper diagram of the water samples in the wet period.

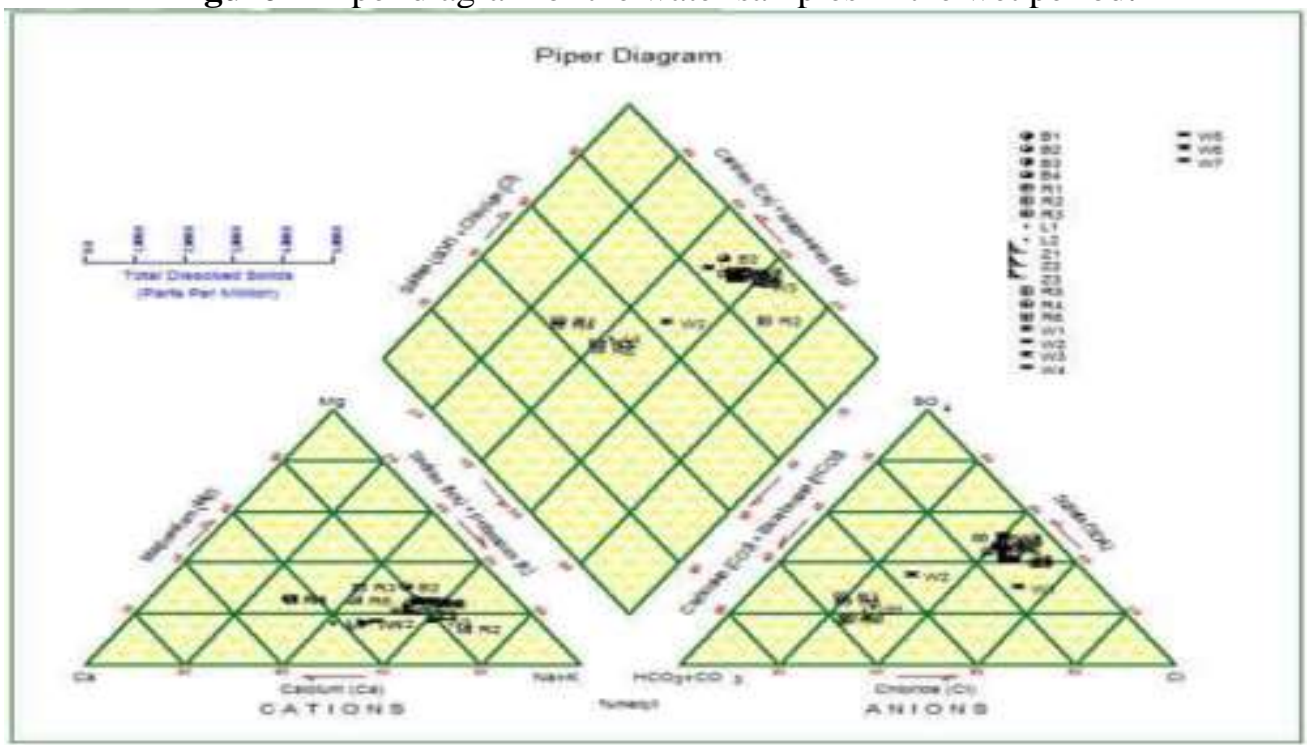

Figure 5-Piper diagram of the water samples in the dry period. 
According to Stiff diagrams (Figure-2) and piper diagrams Figures- $(3,4,5)$ there is a similarity in the chemical composition of water in most of the wells, Bishina springs, along with a similarity between Zwachi springs with some stations of Euphrates River. The differences in the chemical composition of samples from Haditha lake and Bishina springs indicates the presence of inflow between Bishina Springs with some wells, along with the interaction between Zwachi springs and some stations in surface water.

The stable isotopes composition of surface water (Haditha reservoir and the Euphrates River) The results of stable isotopes of the Euphrates River and Haditha Reservoir are presented in Table- 2 .

Table 2-Ec, altitude and stable isotopes data of the Euphrates River and Haditha reservoir for two periods

\begin{tabular}{|c|c|c|c|c|c|c|c|c|c|}
\hline \multirow{2}{*}{ stations } & Altitude & \multicolumn{5}{|c|}{ Dry } & \multicolumn{4}{|c|}{ Wet } \\
\cline { 2 - 11 } & $\mathrm{m}$ & Ec $\mu \mathrm{s}$ & $\square 18 \mathrm{O}$ & $\square \mathrm{D}$ & $\mathrm{d}$-excess & Ec $\mu \mathrm{s}$ & $\square 18 \mathrm{O}$ & $\square \mathrm{D}$ & $\mathrm{d}$-excess \\
\hline L1 & 132 & 1100 & -5.5 & -38.5 & 33 & 970 & -5.89 & -39.5 & 33.61 \\
\hline L2 & 132 & 1126 & -5.58 & -38.45 & 32.87 & 961 & -5.88 & -39.45 & 33.57 \\
\hline R1 & 87 & 703 & -6 & -40 & 34 & 630 & -6.16 & -41.21 & 35.05 \\
\hline R2 & 87 & 3313 & -4.5 & -33.1 & 28.6 & 3111 & -4.9 & -35.2 & 30.3 \\
\hline R3 & 86.9 & 977 & -5.3 & -39 & 33.7 & 848 & -5.8 & -40 & 34.2 \\
\hline R4 & 87 & 715 & -5.9 & -39.7 & 33.8 & 637 & -6.1 & -41.1 & 35 \\
\hline R5 & 86.8 & 2970 & -4.4 & -33 & 28.6 & 2730 & -4.6 & -33.8 & -29.2 \\
\hline R6 & 87 & 1003 & -5.3 & -39 & 33.7 & 934 & -6 & -40 & 34 \\
\hline
\end{tabular}

The isotopic compositions of the Euphrates samples ranged from -41.21 to $-33.38 \%$ for $\square \mathrm{D}$ and from -6.16 to $-4.6 \%$ for $\square{ }^{18} \mathrm{O}$ in March 2018, while they ranged from -40.1 to $-33 \%$ for $\square \mathrm{D}$ and from -6 to $-4.4 \%$ for $\square^{18} \mathrm{O}$ in August 2018. The isotopic compositions of the Haditha reservoir samples varied between -39.5 and $-38.45 \%$ for $\square \mathrm{D}$ and between -5.89 and $-5.88 \%$ for $\square^{18} \mathrm{O}$ in August 2018at the stations L1 and L2 ,respectively. The values for the Hadiths lake samples varied between -38.50 and $-38.45 \%$ for $\square \mathrm{D}$ and between -5.5 and $-5.58 \%$ for $\square^{18} \mathrm{O}$ in August 2018 at the stations L1and L2, respectively Figures-(6 and 7).

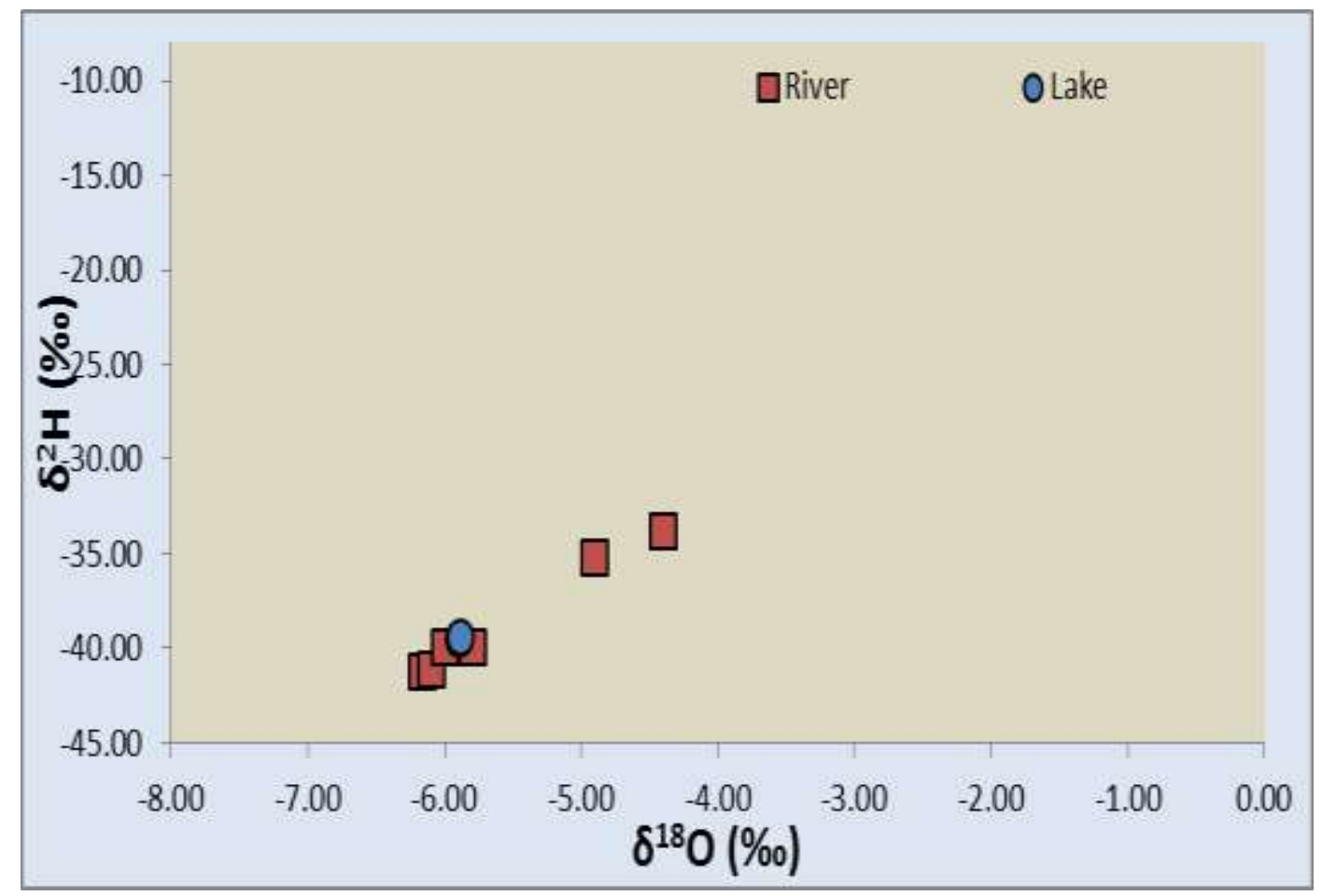

Figure 6-stable isotopes in the Euphrates River and Haditha Reservoir (March, 2018) 


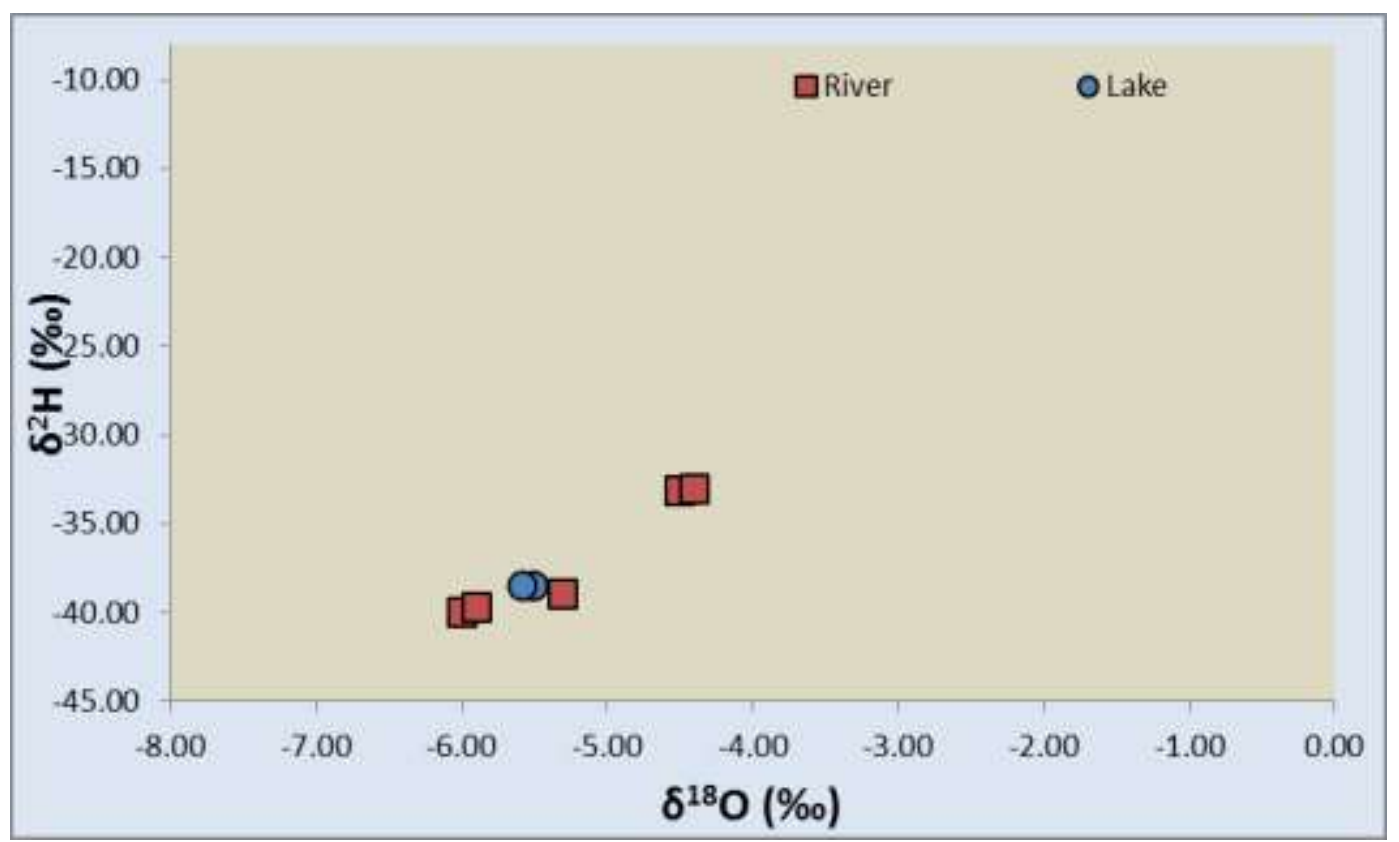

Figure 7-Stable isotopes in Euphrates River and Haditha Reservoir (August, 2018)

An obvious relationship exists between the $\square^{18} \mathrm{O}$ and $\square \mathrm{D}$ of the Euphrates River and Haditha Reservoir, as reflected by the low variation in isotopic values of these two sites due to the effects of the surface area of the Haditha Reservoir (low velocity of water) on the amount of evaporation, as compared to the high velocity and lower surface area of Euphrates River.

\section{The Stable Composition of Groundwater (Springs and Wells)}

Stable isotopes in groundwater (wells and springs) are not only used as tracers of groundwater, but they can also be used to study the quality of groundwater, geochemical evaluation, rock-water interaction, recharge processes, salinity origin, and contaminant processes. In addition, stable isotopes are also employed as indicators to the conditions of the site in terms of precipitation, infiltration, and its origin from surface water or fossil groundwater (Gat and Dansgaard 1972). The isotopic contents of springs water (Bishina and Zwachyi ) and wells in the study area are listed in Table- 3. Local groundwater samples represented seven samples from springs and seven samples from wells within wet (March, 2018) and dry (August,2018) periods.

Table 3-Altitude, Ec and stable isotopes data of groundwater (Bishina, Zwachi wells) in the study area for two periods, 2018

\begin{tabular}{|c|c|c|c|c|c|c|c|c|c|}
\hline \multirow{2}{*}{ stations } & Altitude & \multicolumn{6}{|c|}{ Dry } & \multicolumn{4}{|c|}{ Wet } \\
\cline { 2 - 10 } & $\mathrm{m}$ & $\mathrm{Ec} \mu \mathrm{s}$ & $\square^{18} \mathrm{O}$ & $\square \mathrm{D}$ & $\mathrm{d}$-excess & Ec $\mu \mathrm{s}$ & $\square^{18} \mathrm{O}$ & $\square \mathrm{D}$ & d-excess \\
\hline B1 & 94 & 8111 & -4.49 & -29.5 & 25.01 & 7828 & -4.55 & -30.01 & 25.46 \\
\hline B2 & 94 & 8917 & -4.2 & -28 & 23.8 & 8500 & -4.3 & -28.8 & 24.5 \\
\hline B3 & 93.5 & 8087 & -4.1 & -27.7 & 23.6 & 7847 & -4.2 & -28 & 23.8 \\
\hline B4 & 92 & 8751 & -3.9 & -26.5 & 22.6 & 8451 & -4 & -27 & 23 \\
\hline Z1 & 96 & 9753 & -3.1 & -29 & 25.9 & 9558 & -3.5 & -31 & 27.5 \\
\hline Z2 & 94 & 10547 & -3.1 & -29.1 & 26 & 10371 & -3.4 & -30.1 & 26.7 \\
\hline Z3 & 93 & 10719 & -3 & -29.5 & 26.5 & 10485 & -3.1 & -29.5 & 26.4 \\
\hline W1 & 159 & 4918 & -4.2 & -24.5 & 20.3 & 4784 & -4.49 & -26.5 & 22.01 \\
\hline W2 & 153 & 4538 & -5 & -34.3 & 29.3 & 4397 & -5.42 & -35.76 & 30.34 \\
\hline W3 & 107 & 8076 & -3.9 & -26.5 & 22.6 & 7890 & -4.06 & -27.42 & 23.36 \\
\hline W4 & 98 & 6977 & -4.14 & -33 & 28.86 & 6833 & -4.54 & -35.31 & 30.77 \\
\hline W5 & 97 & 6841 & -4.28 & -30.3 & 26.02 & 6708 & -4.58 & -33.67 & 29.09 \\
\hline W6 & 156 & 7391 & -4.32 & -30 & 25.68 & 7093 & -4.62 & -32.96 & 28.34 \\
\hline W7 & 155.7 & 7099 & -4.24 & -28 & 23.76 & 7281 & -4.54 & -29.02 & 24.48 \\
\hline
\end{tabular}




\section{Temporal Variation}

The $\delta \mathrm{D}$ values in the Bishina springs ranged from $-30.01 \%$ to $-27 \%$ and from -29.5 to $-26.5 \%$ o in March 2018 and August, 2018, respectively; the $\delta{ }^{18} \mathbf{O}$ values in the Bishina springs ranged from $4.55 \%$ to $-4 \%$ and from 4.49 to $-4.1 \%$ in the March 2018 and August, 2018, respectively. While, the $\delta \mathrm{D}$ values in the Zwachi springs ranged from $-31.5 \%$ to $-29 \%$ and from -29.5 to $29 \%$ in March 2018 and August 2018, respectively; the $\boldsymbol{\delta}^{\mathbf{1 8}} \mathbf{O}$ values in the Zwachi springs ranged from $-3.5 \%$ o to $3.1 \%$ and from -3.1 to 3\%o in March 2018 and August 2018, respectively.

The isotopic values of wells in the study area ranged from -35.76 to_29.02\%o and 30.3 to $-26.5 \%$ for $\delta \mathbf{D}$ in March and August 2018, respectively, while they had the ranges of -4.62 to $4.05 \%$ and -5 to-3.9 \%o for $\boldsymbol{\delta}^{\mathbf{1 8}} \mathbf{O}$ in March and August 2018, respectively Figures-(8 and 9).

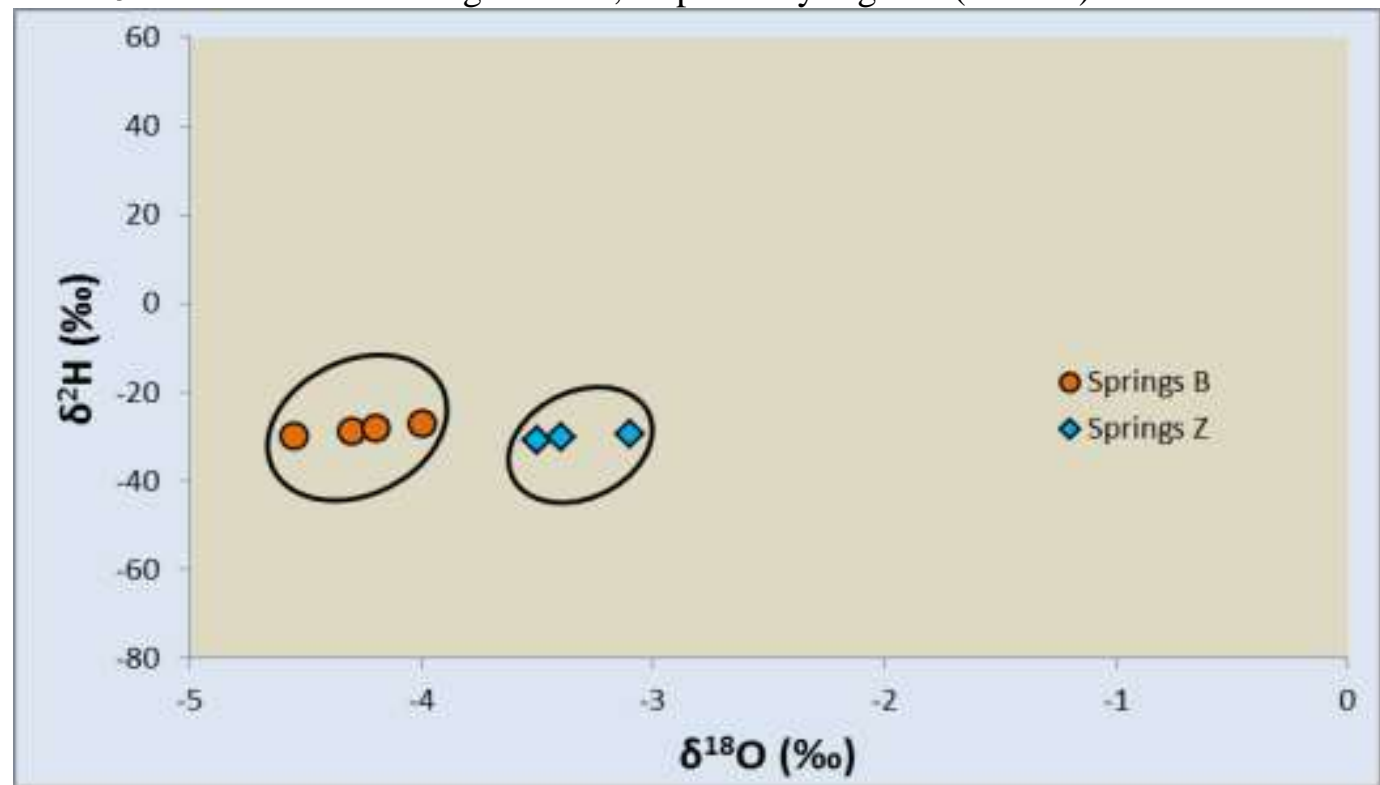

Figure 8-Distribution of stable isotopes values in the Bishina and Zwachi Springs , March, 2018.

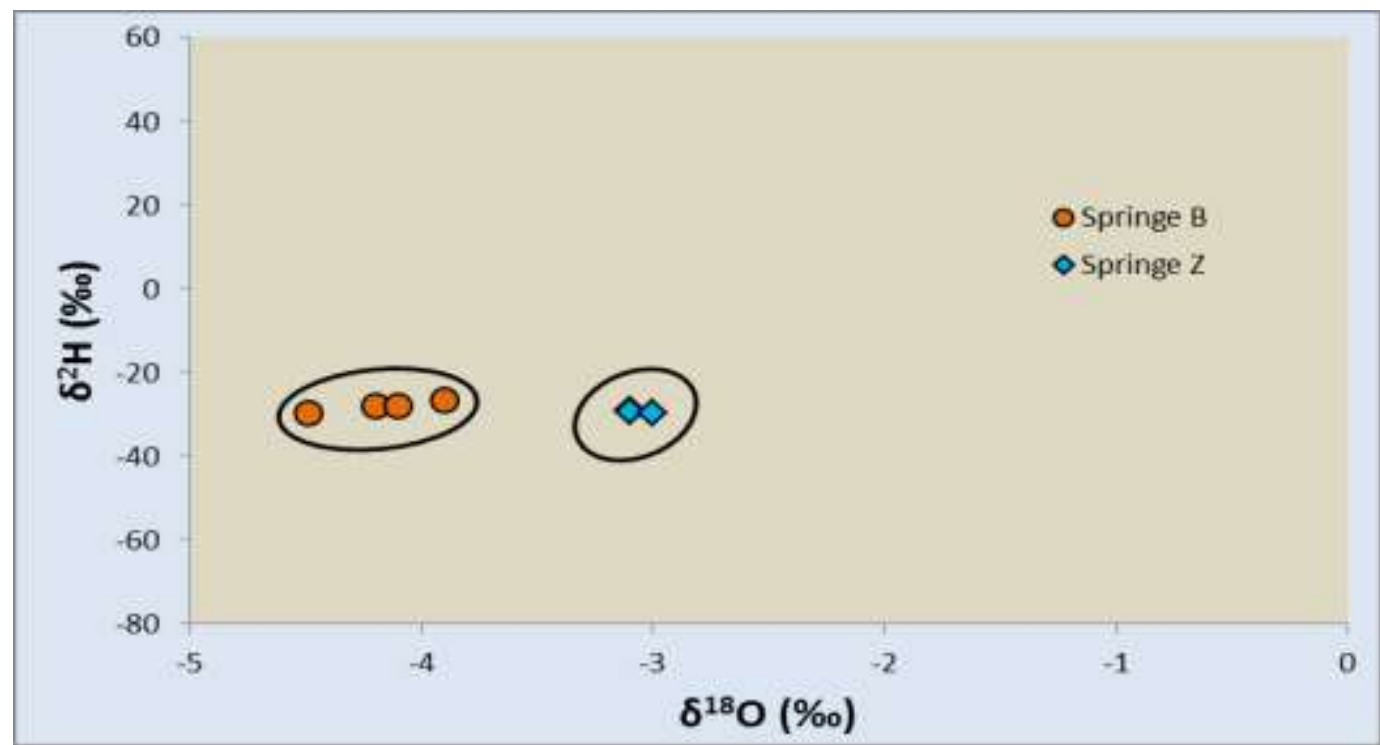

Figure 9-Distribution of stable isotopes values in the Bashina and Zwachi Springs, August, 2018.

is the results demonstrated a variation in isotopic values between Bishina and Zwachi springs, due to factor that appears to modify the isotopic signatures of the springs. Namely, there is a lack of 
hydraulic connection between the springs of Bishina and Zwachi, implying that they recharge from different sources.

Generally, a similar range of isotopes content is noticed within Zwachi springs and groundwater (Wells) in the studied area. The distinct differences of ${ }^{2} \mathrm{H}$ and ${ }^{18} \mathrm{O}$ between Bishina springs and the groundwater can change occasionally, with the fractionation processes throughout their course from the aquifer and the contribution from the reservoir water.

The changes in oxygen isotope composition of the groundwater between the deep reservoir and the springs (Bishina) may be caused by the dilution with near surface water (Haditha reservoir) which has different isotope compositions. In a dry climate, the evaporation of surface waters (river, spring stream, lakes) leads ${ }^{2} \mathrm{H} /{ }^{18} \mathrm{O}$ couples to move away from their meteoric line according to the evaporation line.

\section{Stable isotopes and local meteoric water line (LMWL)}

The relationship between $\delta^{18} \mathrm{O}$ and $\delta \mathrm{D}$ for the springs (Bishina and Zwachi), surface water (Haditha reservoir and the Euphrates River) and groundwater in the study area shows that these waters fall below the global meteoric water line (GMWL), which is at $\delta 2 \mathrm{H}=8 \delta^{18} \mathrm{O}+10$ according to Craig (1961). The GMWL has very wide range of values ( $\delta \mathrm{D}:-300 \%$ to $50 \%$ and $\delta^{18} \mathrm{O}:-42 \%$ to $6 \%$ ). A second measure is the local meteoric water line (LMWL) (Table- 4) [17-19] which was calculated from the weighed annual mean of precipitation. Throughout 18 stations in Iraq, this measure followed a linear regression: $\delta \mathrm{D}=7.53 \delta 18 \mathrm{O}+11.97$. The isotope compositions for any region of the LMWL have different slopes and deuterium excess values than those of the GMWL, thus characterizing the compositions at the local scale [6]. Most waters in this area lie below, or immediately to the lower right, of the LMWL (Figure-10).

Table 4-Previous studies of the local meteoric water line.

\begin{tabular}{|c|c|}
\hline Reference & LMWL \\
\hline Al-Paruany, 2013 [17] & $\delta \mathrm{D}=7.53 \delta^{18} \mathrm{O}+11.97$. \\
\hline Ali et al., 2015 [18] & $\delta \mathrm{D}=7.573 \delta^{18} \mathrm{O}+13.82$. \\
\hline Ali \& Ajeena 2016 [19] & $\delta \mathrm{D}=7.59 \delta^{18} \mathrm{O}+12.04$. \\
\hline
\end{tabular}

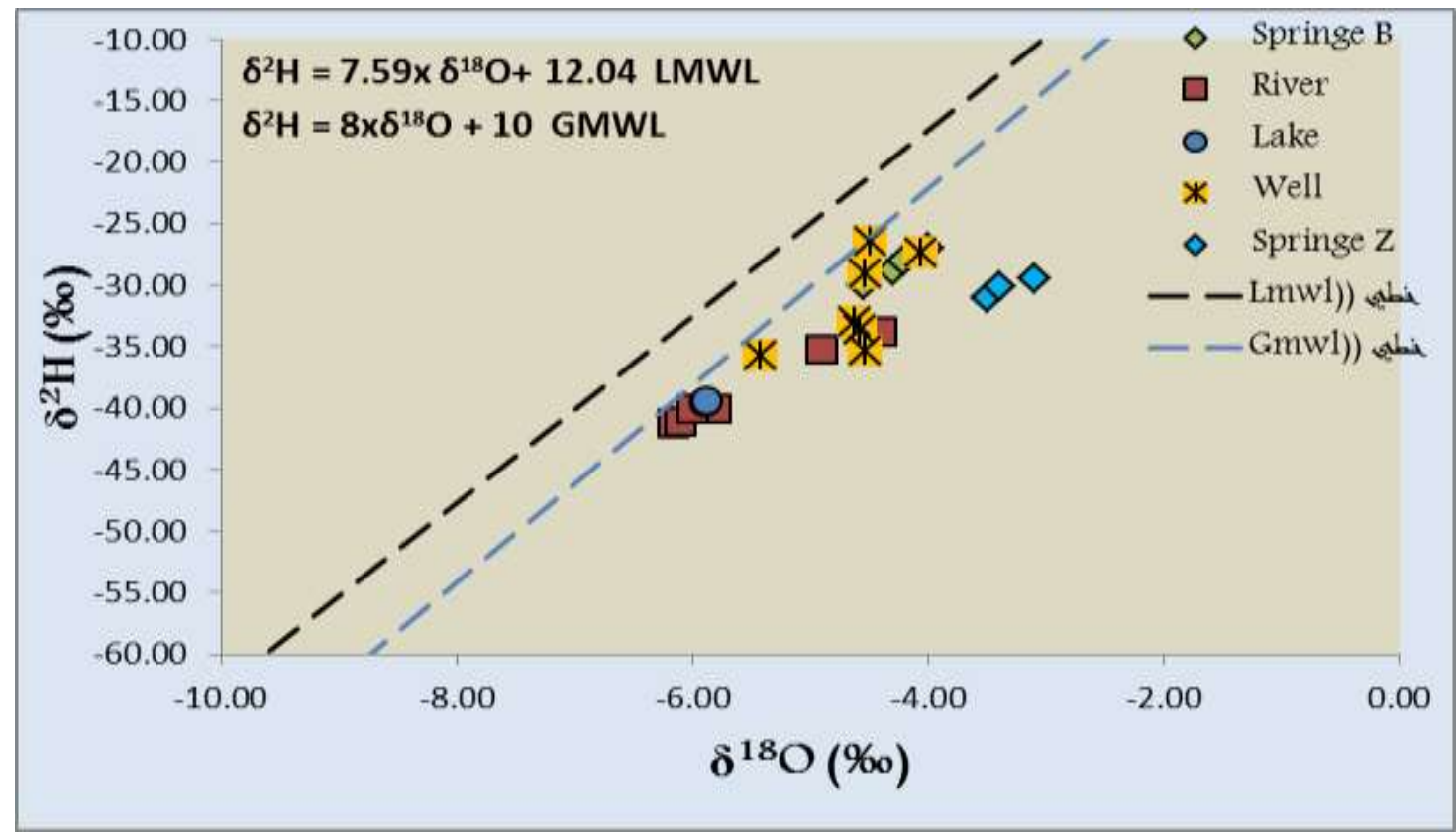

Figure 10-Distribution of stable isotopes values, GWML, LWML in the water resources March, August, 2018.

Here the three different water types are plotted together, following three distinct $\delta^{18} \mathrm{O}$ and $\delta \mathrm{D}$ relationships in the two periods Figures-(11 and 12). 


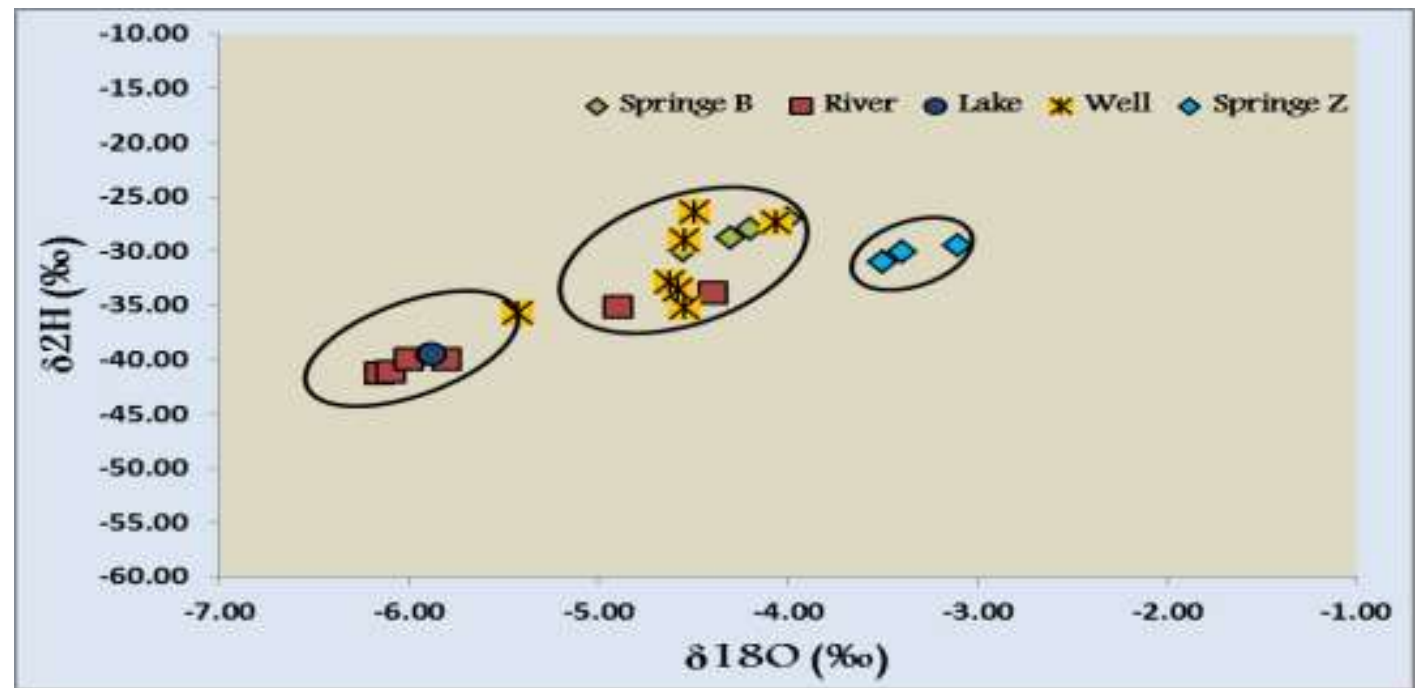

Figure 11-Distribution of stable isotope values in the water resources, March, 2018.

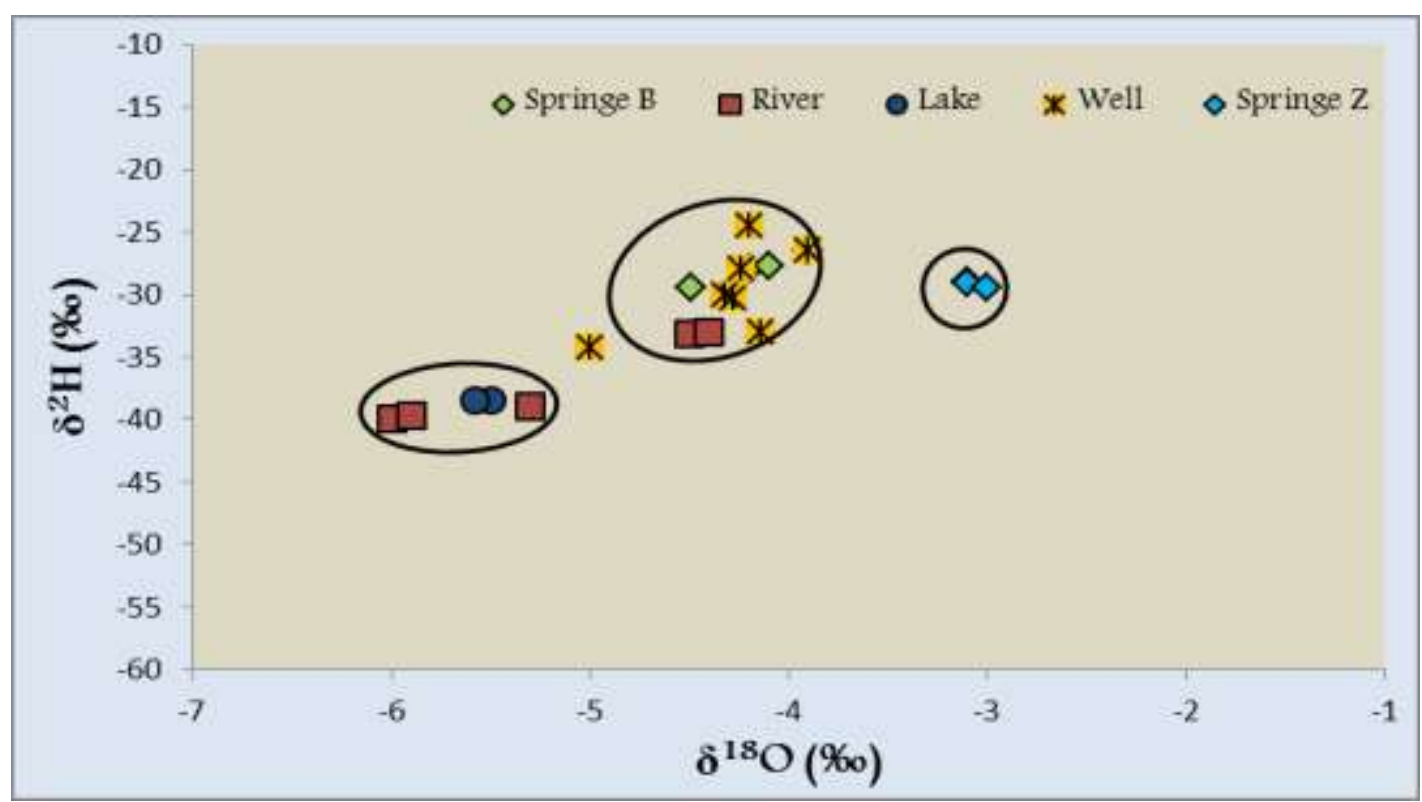

Figure 12-Distribution of stable isotope values in the water resources, August, 2018.

Based on the distribution of the data points on $\delta^{2} \mathrm{H}$ and $\delta^{18} \mathrm{O}$ diagram for water resources in the study area, there is a hydraulic connection between Bishina springs and wells Figures-(11 and 12).

Three groups could be recognized as shown in Table-5.

Table 5-Mean values of $\delta^{18} \mathrm{O}$ and $\delta \mathrm{D}$ for groups of water resources in the studied area.

\begin{tabular}{|l|l|l|l|l|l|l|l|}
\hline \multirow{2}{*}{ Groups } & \multicolumn{6}{|l|}{$\delta^{18} \mathrm{O} \%$ o $\%$ } & \multirow{2}{*}{ Group Name } \\
\cline { 2 - 8 } & Min & Max & Average & Min & Max & Average & \\
\hline Group A & -4.55 & -4 & -3.12 & -30.01 & -26.5 & -26.18 & Bishina \\
\hline Group B & -4.42 & -3 & -2.69 & -35.76 & -29.1 & -22.03 & Zwachi+Wells \\
\hline Group C & -6 & -5.3 & -2.12 & -17.91 & -41.1 & -33 & Surface water \\
\hline
\end{tabular}

Group A has four groundwater samples (B1, B2, B3, B4), group B has two types of samples (W1, W2, W3, W4, W5, W6, W7 and Z1, Z2, Z3), while group C has six samples (L1, L2, R1, R2, R3, R4). The Differences in isotope values in the different groups may be attributed to the different sources of recharge.

Figure-5 shows that most of surface water in the study area lie close to the GMWL and LMWL, which indicates a meteoric origin. This might befrom a higher altitude with an increasing temperature, 
representing the modern Mediterranean precipitation. It also indicates that precipitation of the dry and intermediate zones recharges the springs without significant evaporation prior to the infiltration. Most groundwater (Springs and wells) was below the LMWL, which is attributed to evaporation processes. The spring water (Bishina and Zwachi) samples are clustered together under the MWL, indicating that the spring water has undergone some degree of isotopic modification due to evaporation before recharge.

\section{Deuterium Excess}

In precipitation, $\delta^{18} \mathrm{O}$ and $\delta \mathrm{D}$ relation is so-called meteoric water line. The secondary isotopic variable, deuterium excess, has been demonstrated to be a useful in inferring moisture sources and sub cloud processes [14] [15] [16].

Al-Paruany [17] studied the d-excess in Iraq and showed that the precipitation in Iraq has distinct seasonal variation in $\mathrm{d}$-excess values, with high $(\mathrm{d}>16.9)$ and low $(\mathrm{d}<10.4)$ values [17]. The deuterium excess is a typical character showing the origin of air masses from which precipitation is formed and many factors can effect it such as water vapor and nature of air masses prior to condensation to raindrops (Clark and Fritz, 1997). All the sample values of d-excess in the study area are shown in Figure-13.

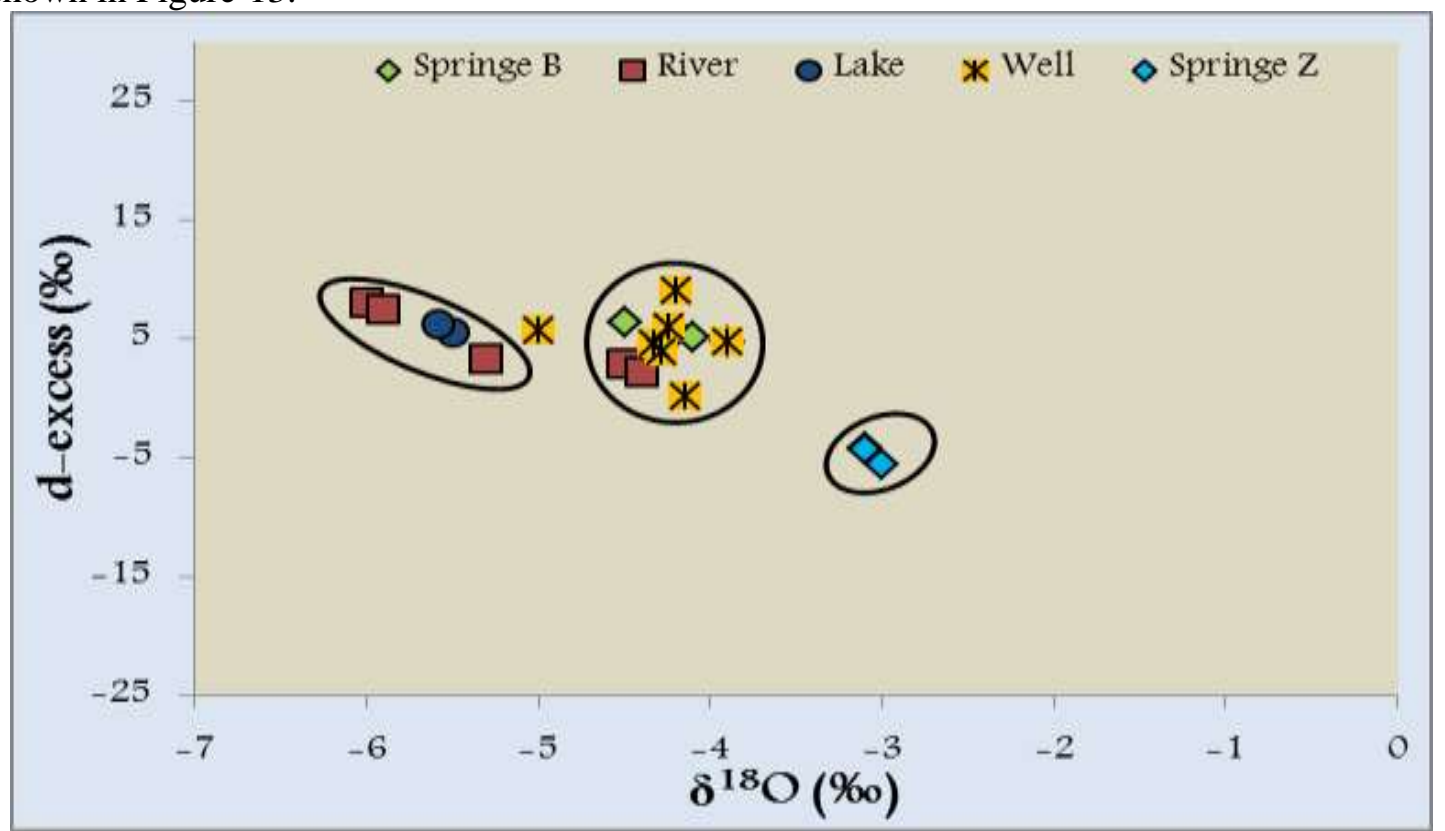

Figure 13-The relationship between O Vs D-excess values in the water esources in the study area, 2018.

The low d-excess of the lake water is resulted from strong evaporation or non-equilibrium fractionation of the lake water. However, d-excess value of Bishina springs water was more than that of Zwachi springs water which are recharged from different sources such as Haditha reservoir. The difference in $\delta{ }^{18} \mathrm{O}$ and $\delta \mathrm{D}$ between Haditha reservoir and the Zwachi springs clearly indicate that the reservoir is not the source of the newly springs water. The two main types of springs water differ in their chemical composition and d-excess as a result of the different alteration products accompanying the water-rock interaction, while it can also indicate different water origin.

\section{Source of salinity}

There are several sources of salinity in the water, some of these sources are natural while others are industrial [20]. Stable isotopes can determine successfully the mechanisms of groundwater salinization and identify the origin of salinity by discussing the relationship between $\delta^{18} \mathrm{O}$ with Ec. The origin of salinization from the dissolution of salts is not accompanied by any significant changes in the stable isotopic composition, but the mixing and/ or evaporation processes are necessarily accompanied by sensitive changes in its stable isotopic composition [21]. Hence, the significant changes between $\delta^{18} \mathrm{O}$ values related with the values of Ec might indicate that the origin of salinity in the study area is from the processes of mixing and/ or evaporation (Figures 14 and 15). 


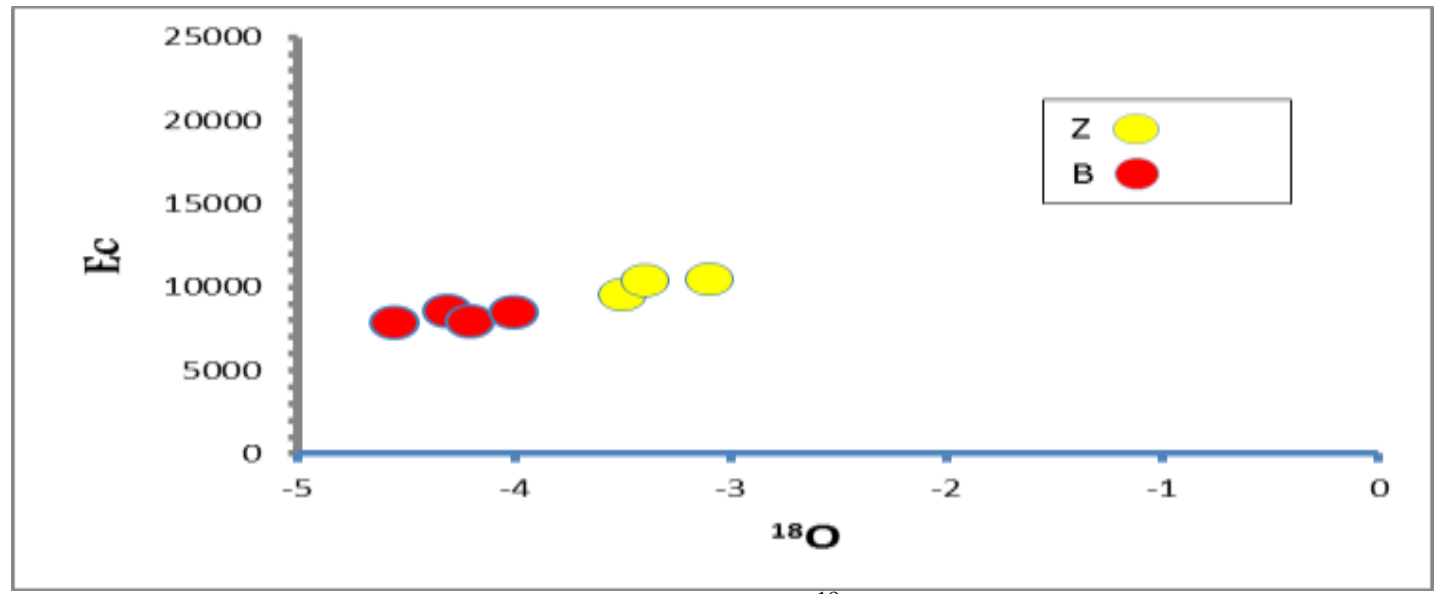

Figure 14-The relationship between $\delta^{18} \mathrm{O}$ and Ec, August 2018.

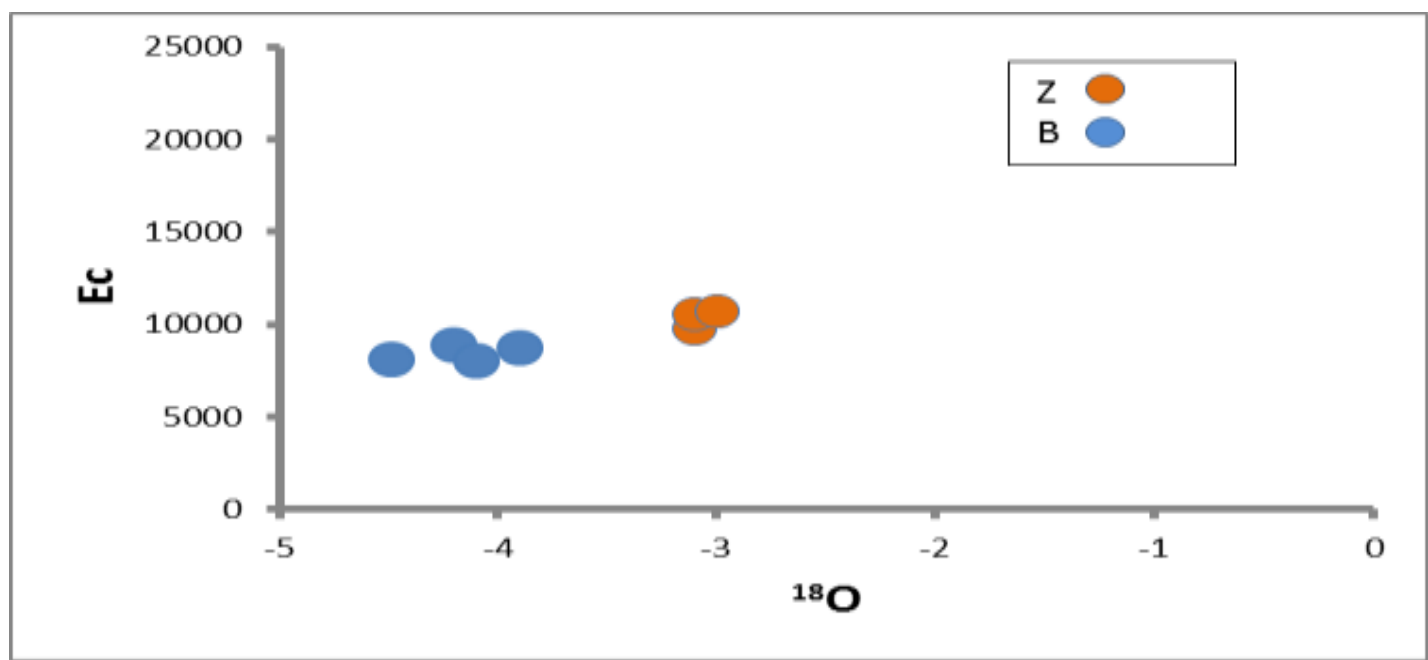

Figure 15-The Relationship between $\delta^{18} \mathrm{O}$ and Ec, March 2018.

From Figures-(14 and 15), it is clear that, prings water during the wet period had low values of salinity $(7828-8500 \mu \mathrm{s} / \mathrm{cm})$ and $\delta 180(-4.55-4 \%$ ), particularly on the Bishina. This can be attributed to the influences of evaporation, dissolution, isotopic depletion by discharge from Haditha Reservoir, and the positive $\mathrm{P}-\mathrm{E}$ in comparison with th dry wet.

\section{Conclusions}

The interaction between groundwater and surface water is complex and varies depending on climate, landform, and geology. An obvious relationship exists between the $\delta^{18} \mathrm{O}$ and $\delta \mathrm{D}$ of the Euphrates river and Haditha Reservoir, which shows that there is a low variation in isotopic values of Haditha Reservoir and Euphrates river due to the effect of surface area of the Haditha Reservoir (low velocity of water) on the amount of evaporation, in comparison with the high velocity and the lower surface area of Euphrates river.

There was a variation in isotopic values between Bishina and Zwachi springs, due to a factor that appears to modify the isotopic signatures of the springs; namely, there is a lack of hydraulic connection between the springs of Bishina and Zwachi, meaning that they recharge from different sources.

Zwachi springs are influenced by Euphrates River and Haditha Reservoir more than Bishina springs, which are influenced by the near wells in the area.

All the samples in study area refer to a higher influence by GMWL than by LMWL.

The changes in Oxygen isotope composition of the groundwater between a deep reservoir and the springs (Bishina) may be caused by dilution with near surface waters (Haditha reservoir) with different oxygen isotope compositions. 


\section{References}

1. Dmitry M, Dan H. and Boris I. 2007. Variations in the isotopic composition of molybdenum in freshwater lake systems; Chem. Geol. 236: 181-198.

2. Kattan Z. 2008. Estimation of evaporation and irrigation return flow in arid zones using stable isotope ratios and chloride mass-balance analysis: Case of the Euphrates River, Syria; J. Arid Environ. 72: 730-747.

3. Stump C., Maloszewski P. and Stichler, W. 2009. Environmental isotope $(\delta 18 \mathrm{O})$ and hydrological data to assess water flow in unsaturated soils planted with different crops; J. Hydrol. 369(2): 198208.4

4. Catherne C G., Alan F M. and Katharine J M. 2010. Hydrological processes and chemical characteristics of lowalpine patterned wetlands, south-central New Zealand; J. Hydrol. 385(3): $105-119$.

5. Sun $\mathrm{C}, \mathrm{Li} \mathrm{X}$. and Chen, Y. 2016. Spatial and temporal characteristics of stable isotopes in the Tarim River Basin; Isotopes Environ. Health Stud. 52(3): 281-297, doi: 10. 1080/ 10256016. 2016.1125350.

6. Clark, I. and Fritz, P. 1997. Environmental Isotopes in hydrology, ewis publishes, new Lewis publishes, New York 328.

7. Jeelani, G., Saravana Kumar, U. and Kumar, B. 2013. Variation of $\delta 18 \mathrm{O}$ and $\delta \mathrm{D}$ in precipitation and stream waters across the Kahir Himalaya (India) to distinguish and estimate the seasonal sources of stream flow. J. Hydrol. 481: 157-165.

8. Ameer, A.S. 1988. Seismic monitoring of al-Baghdadi Dam Site, M.Sc. Thesis, College of Science, University of Baghdad. P120.

9. Mohammad, S.A. 2004. Engineering Geological study of Discontinuities of Al-Baghdadi Dam site (west Iraq). M.Sc. Thesis, College of Science, University of Baghdad, 130p.

10. Al- Hadithy, A.H. 1976. Estimated water balance for the proposed Haditha reservoir on the Euphrates River in Iraq, M.Sc. Thesis, University of Arizona. 245p.

11. Al-Kubaisi, Q. Y. 2004. Annual aridity index of type .1 and type .2 mode options climate classification, Journal of science, $45 \mathrm{C}(1)$ : Iraq.

12. Langguth, H. R. 1996. Groundwater verhaltisse in Bereich des velbertersatues Der-Minister for Ernahrung land, Wistschaft and Forstern, NRW, Dusseldorf, Germany, 127p.

13. Craig, H. 1961. Isotopic variations in meteoric waters, Science, 133: 1702-1703.

14. Masson-Delmotte, V., J. Jouzel, A. Landais, M. Stievenard, S. J. Johnsen, J. W. C. White, M. Werner, A. Sveinbjornsdottir, and K. Fuhrer 2005. GRIP deuterium excess reveals rapid and orbital-scale changes in Greenland moisture origin, Science, 309(5731): 118-121, doi: 10.1126.

15. Liotta, M., Favara, R. and Valenza M. 2006. Isotopic composition of the precipitations in the central Mediterranean: Origin marks and orographic precipitation effects, J. Geophys. Res., 111(D19), doi: 10.10292005 jd006818.

16. Zhang, X. P., Liu, J.M., Wang, X.Y., Nakawo, M., Xie, Z.C., Zhang, J.M. and Zhang, X.Z. 2010. Climatological significance of stable isotopes in precipitation over south-west China, Int. J. Climatol., 30(14): 2229-2239 doi: 10.1002/Joc.2037.

17. Al-Paruany, K.B. 2013. Hydrochemical and a Isotopic study of water resources between Haditha dam and site of Al-Baghdadi Dam. College of Science. University of Baghdad.171p. unpublished. $\mathrm{Ph} . \mathrm{D}$. thesis.

18. Ali, K.K., Alkubaisi, Q.Y. and Alparuani, K. B. 2015. Isotopic study of water resources in a semiarid region, western Iraq, Environmental earth sciences, 74(2): 1671-1686.

19. Ali, K.K. and Ajeena, A.R. 2016, Assessment of interconnection between surface water and groundwater in sawa lake area, southern Iraq, using stable isotope technique, Arabian Journal of geoscience, $9(14)$.

20. Al-Charideh. A.R. 2010. Environmental isotope study of groundwater discharge from the large karst springs in the west Syria, environment Earth, 23(2).

21. IAEA, 2001. GNIP Maps and Animations, International Atomic Energy Agency, Vienna. Accessible at http://isohis.iaea.org. 